\title{
A assinatura colonial e o dispositivo da autenticidade nos Museus.
}

Marcos Alexandre dos Santos Albuquerque (UERJ)

\section{INTRODUÇÃO}

No Brasil o incremento da participação indígena nas curadorias de museus, e na promoção de suas próprias instituições museológicas, teve evidente ampliação nos últimos anos. Minha atividade de pesquisa com etnologia indígena e antropologia da arte me levou ao tema dos museus.

Nesse artigo ${ }^{1}$ aponto alguns questionamentos e problematizações concernente ao modelo de atualização intercultural de tradições indígenas nos museus. Menos do que sugerir um caminho para resolvê-los - pois esta não é a minha pretensão -, procuro trabalhar junto com esses problemas, pensá-los como ferramentas úteis para a análise do contemporâneo. Desse modo, sei que não é nenhuma novidade dizer que o museu é um expediente colonial. Mas, ao mesmo tempo, o esforço de interpretar essa presença/assinatura é um desafio constante para todos nós (ver, por exemplo, Spivak 2010). Precisamos estar alertas para não naturalizar os efeitos do colonialismo na atualidade.

$\mathrm{O}$ artigo está estruturado da seguinte maneira. Inicialmente, faço uma revisão conceitual relativa às categorias de assinatura em Agamben (2006, 2007 e 2014) e de dispositivo em Foucault $(1977,1987)$, reivindicando sua relevância teórico-metodologia para sugerir as categorias de assinatura colonial e dispositivo da autenticidade. Em seguida, apresento a categoria de exótico como um traço positivo do plano da governamentalidade do dispositivo da autenticidade para na sequência propor uma genealogia do museu moderno a partir dos modelos francês e brasileiro. Em um terceiro momento, reflito sobre a relevância de se considerar o contemporâneo como parte do contexto etno-histórico na curadoria museológica e na produção cultural. Por fim, a partir da exposição Uma fração do infinito, do artista Guilherme Vaz, analiso a atuação contemporânea do dispositivo da autenticidade. 
No seu ensaio sobre a nudez, Giorgio Agamben (2014) argumenta que em nossa relação contemporânea com a nudez há impressa uma assinatura teológica. E que é essa assinatura o que realiza a mediação, por exemplo, da nossa experiência com o fetiche sexual. Segundo ele, não há no cristianismo uma "teologia da nudez, mas apenas uma teologia da veste" (ibid.:93). Neste ensaio, o autor investe na problematização da construção do que denomina de "dispositivo teológico natureza (nudez)-graça (veste)" (ibid.:102), onde a nudez "é definida pela não nudez (a veste), da qual foi despida" (ibid.:107), e procura apresentar as condições contemporâneas de desativar esse dispositivo, encontrando nas artes performáticas (e nos museus, portanto) um bom momento disso.

Seguindo uma direção teórica semelhante, acredito que na nossa relação contemporânea com a diferença, o outro, há a presença de uma assinatura colonial que permite a nossa experiência com outro fetiche: o autêntico, o exótico. Nessa assinatura o outro é capturado por dispositivos que na sua origem são exógenos ao contexto desse outro. No colonialismo-modernismo, como condição-mediação do procedimento de captura da diferença, se constitui aquilo que penso ser o dispositivo da autenticidade.

Para Agamben, a assinatura imposta pelo homem "não expressa simplesmente uma relação semiótica entre um signans e um signatum. Ela é, antes, o que, situando-se nessa relação, porém sem coincidir com ela, a move e desloca até outro âmbito, inserindo-a em uma nova rede de relações pragmáticas e hermenêuticas" (Agamben apud Castro 2012:158). Assim, a problemática refere-se "a de uma realidade que é inseparável do signo porém que não pode ser reduzida à relação de significação" (ibid.:160), pois, seguindo W. Benjamin, "é necessário notar que o âmbito próprio das assinaturas é a história" (ibid.:162). Deste modo, por exemplo, com relação ao debate sobre o conceito de secularização no modernismo, Agamben diz:

a secularização atua no sistema conceitual moderno como uma assinatura que se refere a teologia. [...] o conceito secularizado exibe como uma assinatura sua passada pertinência à esfera teológica. O modo como é entendida a referência operada pela assinatura teológica é sempre decisivo. Assim, a secularização também pode entender-se como um aporte especifico da fé cristã, que pela primeira vez abre ao homem o mundo em sua mundanidade e historicidade (ibid.:163).

A noção de dispositivo que aparece em Agamben, e da qual me utilizo aqui, vem do trabalho de Foucault. Segundo um intérprete da obra de Foucault, Edgardo Castro (2009), o dispositivo aparece na segunda parte da obra de Foucault, habitualmente denominada de período genealógico. O dispositivo é o objeto de estudo da descrição genealógica (a episteme seria o objeto da descrição arqueológica) (ibid.:123-4). Assim, arqueologia e genealogia "se apoiam sobre um pressuposto comum: escrever a história sem referir a análise à instância fundadora do sujeito" (ibid.:185). Segundo Castro (ibid.:124), a noção de dispositivo, como parte da descrição genealógica, aparece com a introdução da análise do poder, da relação entre o discursivo e o não discursivo, ou seja, saberes e práticas. Onde se investiga o saber "em termos de estratégia e táticas de poder. [...] tratase de situar o saber no âmbito das lutas" (ibid.:185). Desse modo, as lutas "não são concebidas como uma 
oposição termo a termo que as bloqueia, como um antagonismo essencial, mas como um agonismo, uma relação, ao mesmo tempo, de incitação recíproca e reversível" (ibid.). Por fim, "nessa perspectiva, se poderia falar de uma genealogia dos saberes no âmbito do que Foucault chama de governamentalidade" (ibid.).

Em A Ordem do Discurso (1996), Foucault propõe três regras metodológicas para o conjunto genealógico: o princípio da descontinuidade, da especificidade e da exterioridade (ibid.). Assim, para Foucault, a genealogia "estuda a formação, ao mesmo tempo, dispersa, descontinua e regular [dos discursos] [...] em seu poder de afirmação (ibid.)". Entendo, portanto, que isso significa "não um poder que se oporia ao de negar, mas o poder de constituir domínios de objetos, a propósito dos quais se poderá afirmar ou negar as proposições verdadeiras ou falsas" (ibid.:186).

Portanto, segundo Castro (ibid.:124), por dispositivo no sentido foucaultiano devemos entender:

1) o dispositivo é a rede de relações que podem ser estabelecidas entre elementos heterogêneos: discursos, instituições, arquitetura, regramentos, leis, medidas administrativas, enunciados científicos, proposições filosóficas, morais, filantrópicas, o dito e o não dito. 2) o dispositivo estabelece a natureza do nexo que pode existir entre esses elementos heterogêneos. [...]. 3) trata-se de uma formação que, em um momento dado, teve por função responder a uma urgência. O dispositivo teve, assim, uma função estratégica. 4) além da estrutura de elementos heterogêneos, um dispositivo se define por sua gênese. [...]. 5) o dispositivo, uma vez constituído, permanece como tal na medida em que tem lugar um processo de sobredeterminação funcional.

Agamben escreveu um artigo intitulado "O que é um dispositivo?" (2006). Como demonstra Castro (2012), neste artigo Agamben argumenta que na genealogia foucaultiana do conceito de dispositivo "há que rastreá-lo por meio de outro, positividade" (ibid.:163). Para Agamben, o termo dispositivo "nomeia aquilo no qual e por meio do qual se realiza uma pura atividade de governo sem nenhum fundamento no ser" (ibid.: 164). Agamben "generaliza a noção de dispositivo até fazê-la coincidir com qualquer mecanismo que seja capaz de governar a vida" (ibid.). Portanto, a função dos dispositivos seria:

capturar o vivente, dando lugar, por meio dessa captura, aos processos de subjetivação e de dessubjetivação. Nesse sentido, afirma, 'não seria errado definir a fase extrema do desenvolvimento capitalista que estamos vivendo como uma gigantesca acumulação e proliferação de dispositivos' (p.23). A respeito desse processo, não se trata nem de suprimir os dispositivos nem de imaginar-se ingenuamente um bom uso, mas de profaná-los (ibid.).

Assim, tenho esses parâmetros teórico-metodológicos de fundo. E, para refletir sobre as modalidades pelas quais a assinatura colonial se relaciona com a gestão metonímica do passado e do contemporâneo nos museus, tenho em vista a seguinte questão teórica apresentada por Gonçalves (2002): A nação constituiu um dos seus efeitos de verdade com a objetificação metonímica do tempo (o passado e o contemporâneo). O metonímico (a parte pelo todo) instituiu alguns índices (cultura material e imaterial) como objetificação e metáfora da nação.

Como a gramática básica de um museu articula as figuras de linguagem da metonímia e da metáfora, precisamos em cada contexto identificar o escopo de sua ação e efeitos, assim como promover mecanismos para desativar o dispositivo da autenticidade. Para isso, é necessário tornar pública a ação e a presença 
contemporânea da assinatura colonial, porém, sem perder de vista a diferença, a visibilidade e a agência indígena.

\section{EXÓTICO (TRAÇO POSITIVO DO DISPOSITIVO DA AUTENTICIDADE)}

As noções de autêntico e de exótico fazem parte de nossa experiência histórica na compreensão da diferença. Essa experiência é marcada por uma assinatura colonial. Os museus, as exposições coloniais, os zoológicos humanos, as ciências e as artes, foram os maiores responsáveis por fazerem funcionar estas categorias através da gestão do conjunto metonímico desse Outro.

A palavra "autêntico" é de origem grega, ela se refere ao que consiste num poder absoluto, primordial. Em latim significa o que tem autoridade, é válido, aprovado. O uso moderno da palavra significa várias coisas, como, por exemplo: aquilo de origem (época, fabricação, localidade) comprovada. Aquilo cuja autoria é atestada. Que é reconhecido como legítimo, fidedigno. Algo que não é imitativo pois verdadeiro. Autoridade. Em termos jurídicos aquilo a que se pode dar fé; que está dentro das formalidades legais e é tido como legítimo e verdadeiro. Enfim, aquilo que não é um simulacro, que não é cópia, que é original.

A categoria está plenamente identificada com usos relativos à esfera do poder. Ela é instrumento de administração, de ordem, de regras e leis. Ela aufere legitimidade e, portanto, está constituída no plano da governamentalidade. Na modernidade, no plano da produção discursiva e não discursiva sobre a diferença (o outro), a palavra "autêntico" está curiosamente muito próxima de uma palavra que, aparentemente, Ihe seria oposta, a palavra "exótico". No cromatismo semântico que torna essa categoria produtiva, aquilo que é exótico é autêntico quanto menos nos for familiar.

A objetificação do exótico nas práticas e saberes do plano da governamentalidade o legitima e autentica. Nessa governamentalidade promovida pelo dispositivo da autenticidade, a categoria "exótico" atua como uma das mais produtivas. Assim, por exemplo, o exótico aparece na modernidade associado a diversas áreas do saber, como no caso da legitimação da empresa colonial e do racismo através das exposições coloniais e dos zoológicos humanos; como um gênero no campo das artes; e nas ciências (direito, filosofia, etnologia, museologia e outras).

Voltando, portanto, a Foucault, como parte fundamental do dispositivo da autenticidade, o exótico é condição produtiva desse dispositivo pois: 1) é formado por elementos heterogêneos; 2) nele se estabelece a natureza do nexo que pode existir entre esses elementos heterogêneos; 3) é uma formação que teve por função responder a uma estratégica; 4) define-se por sua gênese; e 5) nele tem-se lugar um processo de sobredeterminação funcional.

Desse modo, essa noção tem uma carga semântica muito forte e carrega um tipo específico de recurso estilístico desenvolvido tanto no discurso das ciências, quanto no das artes (literatura, cinema, fotografia, música, e outros). Uma boa definição geral do termo exotismo pode ser essa: 
Exoticism, by definition, is 'the charm of the unfamiliar'. Scholar Alden Jones defines exoticism in art and literature as the representation of one culture for consumption by another. An archetypical exoticist is the artist and writer Paul Gauguin, whose visual representations of Tahitian people and landscapes were targeted at a French audience. While exoticism is closely linked to Orientalism, it is not a movement necessarily associated with a particular time period or culture. Exoticism may take the form of primitivism, ethnocentrism, or humanism. ${ }^{2}$

O exotismo está filiado a valores diferenciados, sendo usado tanto como valor positivo (humanismo), quanto negativo (etnocentrismo). É nesse sentido que Alden Jones (2007) reconhece que, "to my relief, I landed at the logical: that literary exoticism - the presentation of one culture for consumption by another — was not always 'bad'. It was, in fact, a way to promote cultural dialogue".

Assim, o exotismo promove distintos projetos estéticos-políticos:

(...) das narrativas de viajantes greco-latinos às dos portugueses e espanhóis, as ilhas longínquas e 'afortunadas' marcam uma presença constante, envoltas de elementos fantásticos que espelham medos, ânsias e expectativas de quem descobre, apreende, até certo ponto, e descreve, nem que de forma alegórica, o Outro. O exotismo fundese também com o maravilhoso, sendo estes termos, por vezes, sinónimos e marcas da tentativa de desbravar e domesticar o desconhecido. Assim, O Livro de Marco Polo (1298) recebe também o título de Livro das Maravilhas. (PUGA 2010).

Correspondendo a uma gama muito grande de adjetivos, a palavra "exótico" pode ser sinônimo de “estranho, macabro, diferente, Oriente, tropical, cor local, evasão, pitoresco, longínquo, étnico e países em vias de desenvolvimento" (ibid.). O exotismo é um procedimento típico de uma sociedade que constituiu um lugar de privilégio para a aventura da viagem. Nesse sentido o exotismo é um procedimento de cunho estético cujo significado político é direto, ele é tanto "fruto de pura invenção artística, devaneio criativo e, outras", quanto, "fruto de necessidades de ideologias imperialistas, podendo, então, materializar-se em forma de exótica fantasia" (op. cit).

No campo semiótico o exotismo tende a ser capitalizado, pois "as temáticas e metáforas do exotismo funcionam como 'significantes flutuantes' que veiculam sentimentos, bem como sensações, tornando-se adereços do exotismo como espetáculo onde se fundem diversos marcadores simbólicos e metáforas do desejo de uma apreensão total por parte do Eu-espectador" (ibid.). Nesse campo está situado o contexto dos indígenas nos museus e em performances nas cidades, ou seja, o contexto de que "através de alguns destes lugares comuns, o exotismo torna-se estereotipado na chamada 'aldeia global' onde reina o cosmopolitismo" (ibid.).

O exotismo, portanto, traça um contorno e define "traços e signos da estética da alteridade" que podem ser:

a panóplia de nomes próprios, topónimos, epítetos, expressões e imitação de sons da língua autóctone bem como outros indicadores qualitativos que transportam o leitor para um universo semântico diferente do seu, onde imperam vestes, traços faciais, gestos, objetos característicos, vícios e clichês como o harém (ibid.). 
O campo semântico da noção de exotismo incorpora temas como "o racismo, o escravagismo, a (des) colonização, o nacionalismo, o relativismo, o evolucionismo e a (in)tolerância, condicionados pela visão do Outro como ser mais simples e 'primitivo' ou como ser mais sofisticado e sábio que o Eu" (PUGA 2010). Nesse sentido, a noção de exótico instaura um projeto próprio e "poderá então funcionar como tropos ou técnica de simulacro e desfamiliarização do real como acontece com os índios norte-americanos nos westerns de Hollywood" (ibid.), ou com os indígenas nos museus.

Os discursos que apelam à noção de exótico são:

(...) cobertos de máscaras-artifícios que servem o propósito da ficção, mas deturpam uma visão que, em determinadas situações, se deseja mais real. Todos estes temas e figuras simbólicas se constroem e utilizam recursivamente auxiliando a interpretação do leitor, indo, por vezes, de encontro ao seu 'horizonte de expectativa'. O Outro é então (des)coberto através da ordenação de um mundo semi-encontrado que exige recursos estilísticos e uma linguagem própria para o espelhar. (ibid.).

O caso do termo no campo da música de concerto europeia do século XIX é bem significativo. Nesse campo, exotismo é um gênero no qual ritmos, melodias ou o arranjo orquestral são feitos de forma a evocar a atmosfera de "terras distantes" e "tempos antigos".

Desse modo, o exotismo tinha uma função estética bem definida no campo da música de concerto do século XIX. Como escreveu Dahlhaus (1989) (apud Cazarré 2003:04),

O exotismo musical é uma tentativa de acrescentar uma dimensão musical a uma descrição pictórica, um ambiente remoto e alheio, no palco ou na literatura. (...) sem uma pintura para destacar um ambiente, ou um título que sugira um país de origem os elementos étnicos inseridos na composição erudita europeia são raramente distinguíveis o suficiente para identificar um local específico exceto talvez no caso de algumas danças (ibid.:07).

Como esclarece o autor, este aspecto ilusório não é uma deficiência do gênero, ao contrário, ele é "a sua razão de ser estética: sejam genuínos ou espúrios os estilos étnicos numa ópera ou poema sinfônico são tão imateriais quanto os fragmentos da realidade num romance, quer sejam historicamente documentados ou livremente inventados" (ibid.).

Portanto, "a semelhança de 'autenticidade' passada por uma citação estilística em uma ópera, ou um extrato de uma reportagem de jornal num romance, é um efeito cuja legitimidade não depende de ser genuíno do ponto de vista antropológico ou histórico" (ibid.). É assim que o exotismo e o folclore (folclorismo) possuem "funções estéticas análogas manifestadas musicalmente por dispositivos estereotipados usados para representar ambientes locais e estrangeiros" (ibid.:07).

É curioso observar que o exotismo é também, nesse sentido, um projeto de tradução intercultural que preza pela utilização de códigos não discursivos para se fazer valer como positivo. Tal como escrito por Puga (2010), o exotismo é: 
Uma metáfora representativa do encontro de diversas esferas civilizacionais, apresenta-se como uma questão de identidade, de pertença sociocultural; uma questão ontológica e também gnoseológica, um jogo de espelhos transversal a todas as manifestações artísticas, filtrado quer pela sensibilidade de quem o elabora quer pelo contexto histórico-cultural da sua produção e posterior recepção.

O exotismo é "transversal a todos os gêneros" artísticos, ele "enquanto fenómeno literário e social, não apresenta uma poética particular, evocando o longínquo e o estranho de forma diferente ao longo dos tempos" (ibid.).

O exotismo é, portanto, um tipo de discurso político-estético que abarca um modelo político de gestão "cultural" do outro ao mesmo tempo em que fundamenta um estilo artístico como uma forma e não propriamente um conteúdo. A “estética do diverso" (Segalen apud Puga 2010), apela então a um imaginário “policromático e atraente para escritores, com base num saber multicultural progressivamente acumulado, uma vez que a descoberta empírica da diferença do Outro, sendo multidimensional e fruto de contemplação emotiva é algo difícil de se conseguir de uma forma objectiva" (ibid.).

Portanto, transpondo os campos do saber, no tempo e no espaço, o exótico não realiza apenas uma viagem geográfica, às vezes nem isso, fundamentalmente o exótico realiza uma viagem no tempo, um ato de tempo. É nesse sentido que o exótico aparece no discurso ocidental associado ao colonialismo do século XIX e XX como constituindo a categoria de ouro que define o outro radical do ocidente, fundamentalmente o "atrasado", quando não o "primitivo". Nesse contexto, a categoria exótico existe para definir de uma forma geral o outro radical. O exótico, como uma categoria (analítica e formal), só pode se tornar efetiva se "existir", se presentificar, aparecer concreta e simbolicamente ao se realizar no trabalho dos artistas (pintores, escritores, fotógrafos, cineastas) ou dos funcionários do estado (museólogos, etnógrafos, administradores).

É a fórmula aventura-viagem e o que ela produz nas artes (literatura, fotografia, música, cinema), nas disciplinas (etnologia, museologia, administração), e nas instituições (museus, exposições coloniais, zoológicos humanos). Através da rentabilidade dos seus objetos, tanto os virtuais (os relatórios, as descrições, as etnografias e outros), quanto os concretos (os objetos, a cultura material). O exótico, em suma, é aquilo que foi capturado (metonímia) como sendo o outro e objetificado nesses campos (artes, disciplinas e instituições). A viagem como um ato de tempo que realiza a categoria exótico institui o outro como alegoria do ocidente.

Entre o século XIX e início do XX, no período mais lucrativo do colonialismo europeu, tanto os museus quanto os zoológicos humanos (e as exposições coloniais e/ou universais) serviam a popularização do racismo e, consequentemente, promoviam a legitimidade da empresa colonial. Os museus [etnográficos] serviam para um gosto mais aristocrático e burguês, enquanto os zoológicos humanos atraiam um amplo público. Os zoológicos humanos e seus congêneres participaram da invenção do selvagem e da diferença como subtração. Alguns personagens desses zoo`s tornaram famosas trágicas histórias pessoais, como Saara Bartman na Europa e Ota Benga nos EUA. 
Na passagem entre os séculos XIX e XX houve o recrudescimento da luta por direitos sociais nos países coloniais e, ao mesmo tempo, o incremento da participação econômica e política dos países colonizados. Com isso os zoológicos humanos foram desaparecendo. Mas, ao mesmo tempo, com o advento do cinema, houve uma transposição, tendo o cinema assumindo o projeto da popularização do racismo e legitimação da empresa colonial. O cinema toma o lugar dos zoológicos humanos e amplia, ainda mais, o alcance desse tipo de imagem e de discurso metonímico sobre o Outro. Hoje os museus ganharam nova relevância no mercado de bens simbólicos, tendo ampliado o seu alcance com a popularização da internet e do turismo, tornando-se ainda mais nosso contemporâneo e formador de opinião.

Portanto, qual a natureza da permanência dessa assinatura colonial nos museus [etnográficos] atuais? Como lidar com essa assinatura? Quais os seus efeitos na atualização intercultural de tradições indígenas? A vanguarda indígena acessa a instituição colonial como espaço de não coetaneidade (Fabian 2013)? É possível nos libertarmos do passado de um conceito/instituição? É desejável? Problematizo aqui não o apagamento da assinatura colonial nos museus, mas os efeitos do dispositivo da autenticidade na formação dos museus, da antropologia e do conjunto difuso do imaginário sobre a diferença, sobre o outro.

\section{UMA GENEALOGIA DO MUSEU MODERNO}

A autenticidade é um valor moderno, e o tradicionalismo é uma de suas vertentes. A noção de que o passado está "se perdendo" e deve ser, de alguma forma, "preservado" é o sintoma de uma mudança histórica e social que caracteriza a modernidade. O colonialismo aparece como "mal necessário" e positividade do poder na produção de registros administrativos, etnográficos, museológicos e outros. Desse modo, apresento aqui o padrão francês de museologia e de etnografia que se tornou o modelo dos pesquisadores e funcionários do governo brasileiro para o registro e a constituição de "patrimônio cultural nacional".

A forma como um índice indígena surge como tradição a ser preservada em museu (descoberto, registrado em áudio e imagem, descrito, catalogado, adquirido e por fim arquivado) se encontra no contexto desse modelo francês de constituição de patrimônio e registro onde a etnografia é um dos suportes científicos. O campo da etnografia e da museologia brasileiros nos anos 1930 estava fortemente influenciado pelos franceses, principalmente pelos modernistas paulistas na recém fundada Universidade de São Paulo (USP) onde se encontrava uma comitiva francesa. Nesse mesmo espírito, essa aliança intelectual fundou a Sociedade de Etnografia e Folclore (1936) cujos "patriarcas" foram Mário de Andrade e o casal Dina Dreyfus e Claude Lévi-Strauss.

Desse modo, proponho começar no "lugar" em que se produziram as principais questões relacionadas ao imaginário sobre os povos "colonizados" no começo do século XX que influenciaram o contexto do colonialismo interno no Brasil.

Assim, concordo com Peixoto (2006: 290) quando afirma que: 
A atração pelo exótico não apenas se mantém na passagem do [século] XIX para o XX, como ganha novo fôlego. O exílio em terras distantes foi o caminho escolhido por inúmeros europeus, artistas em geral, numa tentativa de descoberta de outros povos e culturas, o que possibilitava a reavaliação do próprio ser europeu. Mas se o exílio e as viagens isoladas de pintores e literatos significam um alargamento de horizontes para a Europa, não foram as únicas. A ciência - a antropologia principalmente - colocava-se como um acesso seguro para o conhecimento de novos povos e culturas.

Como é de conhecimento no meio antropológico, até o final da primeira década do século XX a etnografia e a pesquisa de campo não eram uma grande tradição na França. Foi em Paris, em 1925, que Paul Rivet, Lucien Lévy-Bruhl e Marcel Mauss criaram o “Institut d'Ethnologie”, onde, pela primeira vez na França passou a existir "uma organização cuja preocupação principal é o treinamento de pesquisadores de campo profissionais e a publicação de estudos etnográficos" (Clifford 2002:138). Paul Rivet compreendia perfeitamente que "a criação de instituições de pesquisa antropológica requeria uma onda de entusiasmo por coisas exóticas. Tal moda podia ser explorada financeiramente e canalizada no interesse da ciência e da educação do público" (ibid.:145). Georges-Henri Rivière foi contratado por Rivet para "reorganizar o Trocadéro, cujas coleções estavam maltratadas e em total estado de desorganização e abandono" (ibid.). Esse trabalho e amizade resultou na criação do Musée de l'Homme (ibid.).

Rivet "proporcionou o apoio institucional que, juntamente com os ensinamentos de Mauss, formaram o centro para uma emergente tradição de trabalho de campo. Para a maioria desses pesquisadores, a conexão entre arte e etnografia era crucial" (ibid.:159). Assim, a outra força poderosa do projeto foi Marcel Mauss. Na década de 1930, Mauss treinou "um seleto grupo, um grupo de devotos, alguns deles amantes do exótico, então em moda, outros, etnógrafos que se preparavam para ir para campo (alguns dos primeiros em vias de se transformarem nos segundos)" (ibid.:139-40).

No Musée de I'Homme "o homem total de Mauss seria pela primeira vez composto para a edificação do público" (ibid.:159). Inaugurado em junho de 1938, o Musée de l'Homme foi concebido como parte da Exposição Internacional de 1937 (ibid.). O Musée de l'Homme foi pensado para substituir o Museu de Etnografia do Trocadéro. Durante a década de 20 esse museu se "apoiava na onda de entusiasmo pela art nègre, (...) o termo nègre podia abranger o moderno jazz americano, as máscaras tribais africanas, o ritual do vodu, as esculturas da Oceania, e até mesmo artefatos pré-colombianos" (ibid.:157).

O termo nègre tinha "alcançado as proporções do que Edward Said chamou de 'orientalismo' - uma bem articulada representação coletiva expressando um mundo geográfica e historicamente vago, mas, em termos simbólicos, nitidamente exótico", (ibid.). A noção de 'fetiche' africano nos aos 1920:

(...) descrevia não uma modalidade de crença africana, mas sim o modo pelo qual artefatos exóticos eram consumidos pelos aficionados europeus. Uma máscara ou uma estátua ou qualquer traço de cultura negra podia efetivamente resumir um mundo de sonhos e possibilidades - apaixonado, rítmico, concreto, místico, incontido: "África". (ibid.). 
Assim, "esse interesse pela África tinha se tornado um exotisme no sentido pleno do termo" (ibid.).

Em 31 de março de 1931, o Parlamento Francês aprovou uma lei especial criando a Missão Dakar-Djibouti, "a primeira tentativa de pesquisa etnográfica sistemática, apoiada e financiada pelo governo, realizada por franceses em contexto exótico" (Motta 2006:263). A Missão "além de lançar, a longo prazo, um programa de pesquisas etnográficas, previa a constituição de um acervo para o Museu de Etnografia do Trocadéro, posteriormente denominado Musée de l'Homme." (Motta 2006: 263).

Além de verba pública, a Missão contou com o apoio da iniciativa privada (empresariado) e de mecenas das artes (ibid.:156). A expedição, dirigida por Marcel Griaule, partiu da França no dia 19 de maio de 1931 e retornou no dia 16 de fevereiro de 1933. Segundo Clifford (2002:157), “Os etnógrafos partiram em $1931 \mathrm{com}$ uma estética estruturada na cabeça, uma visão da África e uma certa concepção (essencialmente fetichista) de como 'ela' deveria ser coletada e representada".

A Missão privilegiou, "antes de tudo, a coleta de objetos etnográficos que deveriam complementar e preencher as lacunas das coleções africanas do Museu de Etnografia." (Motta 2006: 264). O mais interessante é que o programa do projeto previa "que as formações de coleções não poderiam ser conduzidas pela escolha arbitrária dos pesquisadores, norteada apenas por suas idiossincrasias momentâneas ou emoções estéticas" (ibid.). Para isso,

(...) o material coletado deveria ser rigorosamente classificado, sem perder de vista a sua funcionalidade, a qualidade das técnicas de fabricação, formas, dinâmicas e representações. Visto dessa perspectiva, o objeto etnográfico deveria ser "desierarquizado", isto é, contemplado não em função de seu valor estético ou da raridade que eventualmente pudesse possuir e comunicar, mas antes em função da sua representatividade e do seu valor enquanto testemunho e expressão de uma determinada cultura (ibid.).

Rivet e Rivière publicaram no segundo número da revista surrealista Minotaure (1933), o resultado da Missão (3.500 objetos, 6 mil fotografias, 300 manuscritos e amuletos, e outros), nas palavras de ambos, "este 'butim' da expedição, era a expressão pública de uma missão bem sucedida" (apud Clifford 2002: 176).

Como lembra Clifford (ibid.), "Barthes (1957:140) disseca a palavra missão; chama-a de um 'termo mana' imperial, que pode ser aplicado a qualquer empreendimento colonial, dando-lhe uma aura redentora e heroica" (ver nota 10). Michel Leiris que integrou essa Missão e, posteriormente, foi funcionário por três décadas do Musée de l'Homme, "refletiu sobre o paradoxo de um museu dedicado às artes da vida. O perigo, escreveu, era que, 'a serviço daquelas duas abstrações chamadas arte e ciência, tudo aquilo que é fermentação vital' seja 'sistematicamente excluído'" (ibid.: 165).

A arte, "agora uma essência universal, é exposta e aprovada por um bom senso idealista e confiante" (ibid.). Uma humanidade, "completa e estável é confirmada. Tal totalidade pressupõe uma omissão, a excluída fonte de projeção. O que não estava exposto no Musée de I’Homme era o Ocidente moderno, sua arte, suas instituições e técnicas" (ibid.: 166). 
Quanto vale esse material? É possível calcular seu valor econômico, simbólico, político ou científico? Clifford escreveu que:

(...) o processo de pesquisa que começou com a Missão Dakar-Djibouti produziu uma das mais completas descrições de um grupo tribal (os Dogon e seus vizinhos) jamais registrada. Ainda assim, como assinala Mary Douglas (1967), o quadro está curiosamente 'distorcido'. (...) a extraordinária beleza e poder conceitual da sabedoria dogon, conhecida em toda a sua amplitude apenas por um pequeno grupo de pessoas mais velhas, nunca satisfaz a incomoda pergunta: como são realmente os Dogon?. (ibid.: 158)

E quem são e o que pretendem os etnógrafos ao ir para campo? Peixoto (2006: 288) escreveu que Lévi-Strauss e Michel Leiris "tematizam a viagem como traço inseparável da experiência etnográfica em obras de perfis distintos". Lévi-Strauss, através de seu livro Tristes Trópicos, e Leiris com o seu A África Fantasma. Nessas obras estão presentes "elementos preciosos para que pensemos a viagem como experiência constitutiva (e instituinte) do trabalho antropológico: a viagem sonhada (como aventura) e a viagem vivida (como decepção), (...) como diálogo com o imaginário construído sobre os povos 'exóticos' e sobre o viajante" (Peixoto 2006: 288).

Concordo com Peixoto (idem: 289) e sigo seu trabalho que se situa na perspectiva de que:

A riqueza do cotejo das duas narrativas reside também na possibilidade de compreensão do processo de formação do etnólogo na França dos anos 1930, quando se realizam as primeiras grandes pesquisas de campo. O caminho seguido por ambos, que não tinham formação básica em etnologia, foi a viagem.

E nessa viagem à procura do exotismo como "rito de passagem" e aventura, "é de decepção que nos fala Leiris; decepção do mesmo tipo daquela que sente Lévi-Strauss ao encontrar os trópicos mais cheios de misérias que de esplendores (...) o regresso, definido antes por frustrações que por conquistas" (ibid.: 300).

Desse modo sua conclusão é a de que:

A decepção com a viagem e com a realidade encontrada aparece com muita força no relato de viagem do século $X X$, mas não é a sua marca registrada, seu traço exclusivo, já que esses elementos podem ser encontrados nos escritos dos antigos viajantes. O que talvez distinga a narrativa 'moderna' é a decepção do viajante consigo próprio e com a sua civilização. A viagem agora, de modo mais radical, coloca o viajante diante de um espelho: onde ele pensa encontrar o outro, vê a si mesmo (Peixoto 2006: 295-6).

Normalmente, o relato do viajante que retorna, seja através do texto, seja da pintura, do registro em áudio ou mesmo em vídeo, procura mostrar aquilo que seria o oposto do "ocidente", promovendo uma retórica que acentue o exotismo não apenas do "outro mundo", mas também o de sua própria experiência, valorizando assim sua viajem. A decepção de que falam os relatos mais honestos de viajantes-etnógrafos (como Lévi-Strauss e Leiris) advém do fato de que o "ocidente" por vezes está também nesse "outro mundo", e tudo o que o viajante não quer é viajar para o "mesmo lugar". Esse "ocidente" que se estende para o mundo exótico tende a substituir com violência esse "outro mundo" que surge assim nessas narrativas como "frágil".

Embora o exótico (a viagem, a aventura e o outro) possa ser decepcionante, ele sempre rendeu aos cientistas-viajantes um rico conjunto de cultura material que veio a constituir o reservatório do colonialismo 
humanista e marca positiva de seu empreendimento economicamente oneroso. E isso porque esse outro patrimonializado (cultura material) veio a representar simbolicamente nos museus a marca final do domínio das nações imperialistas e o seu humanismo tutelar sobre todos os outros povos e colônias. Os museus dos países imperialistas pretendiam definir a história do "humano" e sua forma no mundo - poder simbólico, estético, econômico e político -, através da instituição desse outro homogêneo, o exótico, distinguível no conjunto do patrimônio encontrado, descrito, gravado, filmado, adquirido, catalogado e arquivado. ${ }^{3}$

\section{MODERNISMO BRASILEIRO}

O modernismo brasileiro estava fortemente influenciado pelo recente projeto dos antropólogos franceses em constituir patrimônio cultural com peças coletadas em Missões patrocinadas pelo poder público nas colônias francesas. Esse projeto estava em consonância com a ideia de que nessas colônias o ingresso do estilo de vida colonial colocava em risco o patrimônio especifico desses povos e assim as viagens dos etnógrafos permitiam o conhecimento e a aquisição do patrimônio "ameaçado" desses lugares.

No Brasil, esse espírito também se fez presente na década de 1930 entre os chamados modernistas com forte tendência nacionalista. Como escreveu Gonçalves (2002:31) "as estórias narradas por intelectuais nacionalistas sobre o patrimônio cultural brasileiro são, basicamente, estórias de apropriação, narradas para responder a uma situação de perda e com o propósito de construir a nação". A noção de patrimônio desses intelectuais situava-o em um processo de "desaparecimento ou destruição, sob ameaça de uma perda definitiva" (ibid.). Como enfatiza Gonçalves ao longo de seu estudo, a narrativa sobre o patrimônio brasileiro pressupunha uma "situação primordial feita de pureza, integridade e continuidade, situação esta seguida historicamente por impureza, desintegração e descontinuidade. A história, de certo modo, é vista como um processo destrutivo" (ibid.).

E, portanto, como forma de "fazer frente a esse processo estabelecem-se estratégias de apropriação e preservação do patrimônio. Nesse sentido a nação, ou seu patrimônio cultural, é construída por oposição a seu próprio processo de destruição" (ibid.). Segundo Gonçalves (ibid.:39) os intelectuais que estavam engajados nesse projeto de salvar o patrimônio brasileiro eram arquitetos, historiadores, escritores, cientistas sociais e outros que em sua maioria eram "unanimes em situar o início das políticas oficias de patrimônio cultural no Brasil em 1936, quando a criação de uma agência federal de proteção ao patrimônio foi oficialmente proposta".

Assim, em 1936 Mário de Andrade foi convidado a escrever o projeto para a criação de uma instituição nacional de proteção ao patrimônio cultural brasileiro e, em 1937, com o Estado Novo de Getúlio Vargas, o Serviço de Patrimônio Histórico e Artístico Nacional (SPHAN) foi criado (ibid.: 42). ${ }^{4}$ No decreto de criação do SPHAN o patrimônio histórico e artístico nacional é descrito como constituído pelo "conjunto de bens móveis e imóveis existentes no país e cuja conservação seja de interesse público, quer por sua vinculação a fatos memoráveis da história do Brasil, quer por seu excepcional valor arqueológico ou etnográfico, bibliográfico ou artístico" (SPHAN apud Gonçalves 2002: 67, grifo meu). 
Ainda no ano de 1937 Rodrigo Melo Franco de Andrade tornou-se diretor do SPHAN, "seu nome está metonimicamente associado ao processo de formulação e implementação de uma concepção de 'patrimônio histórico e artístico' por meio da qual a moderna identidade nacional brasileira veio a ser visualmente representada ao longo das cinco últimas décadas" (ibid.). O discurso de Rodrigo sobre o patrimônio brasileiro é marcado por um viés evolucionista, nesse discurso "a civilização é narrada como o resultado de um processo universal de evolução, desde os estágios mais 'primitivos' até os mais 'avançados'" (ibid.: 45). Nesse sentido, esse patrimônio é associado “'às populações primitivas como as que nos constituíram', especialmente, africanos e ameríndios. Suas culturas são vistas como os remanescentes de um passado desaparecido (ou em processo de desaparecimento), mais do que como formas atuais de vida social e cultural" (ibid.).

Em resumo, as populações indígenas e afro-brasileiras eram pensadas como situadas

(...) em estágios ultrapassados de evolução cultural e, desse modo, ignoradas em termos de sua vida social e cultural presente. Ao mesmo tempo, os valores 'primitivos' e 'exóticos' associados a essas populações eram integrados à narrativa modernista de Rodrigo como exemplos de valores culturais e estéticos supostamente universais, do mesmo modo que a arte e as culturas primitivas vieram a ser integradas ao quadro universalista da vanguarda modernista europeia dos anos 20 (Gonçalves 2002: 45-6).

Rodrigo Melo Franco de Andrade chegou a escrever que “o acervo dessas produções da sucessão já longa de nossos predecessores é que, ligando os brasileiros de hoje às populações que os antecederam, originários da própria terra ou provindas de outros continentes, em verdade autentica e afirma a existência do Brasil" (Andrade apud Gonçalves 2002:37).

É nesse sentido que a metonímia do Outro funciona como espaço para a construção metafórica da nação. O Outro como condição de um objeto-museu, um objeto fetiche para o discurso modernista sobre o patrimônio do Brasil. ${ }^{5}$

\section{CONTEXTO [ETNO]HISTÓRICO}

Franz Boas teve reconhecida participação na curadoria museológica nos EUA entre fins do século XIX e primeira metade do século XX. Sua premissa antropológica baseada no particularismo histórico se opunha ao consenso em torno das hipóteses evolucionistas. Com relação aos museus, essa premissa pressupunha a contextualização dos itens de cultura particulares nas exposições nos museus. Os objetos de uma cultura devem remeter uns aos outros em seu próprio contexto social de origem e não a disposições evolucionistas (Boas 2004).

Como lembrou Clifford, na citação mais acima, essa premissa boasiana pode ser ampliada e enquadrar um campo maior do contexto que constitui uma curadoria museológica. Como, por exemplo, enquadrar o próprio curador, a instituição em si, e, a historiografia da relação entre os atores sociais envolvidos no projeto de escolha do conjunto metonímico. 
A atuação da assinatura colonial nos museus toma o índice por ele mesmo, sem contextualizá-lo, sem historicizá-lo, sem atualizá-lo. Os objetos (e a cultura imaterial) são traços que na sua condição de componentes de uma cosmologia são, por isso mesmo, objetos da condição política dessas sociedades. Além de uma cosmologia, os objetos indígenas têm uma história, uma política. Na verdade, os índices/objetos são os eixos de inúmeras camadas sociais. Separar política de cosmologia é pouco produtivo. Pois, geralmente, é do campo religioso que a gramática da política indígena retira suas categorias de existência e possibilidade. A ética que as promovem são, cosmológica e instrumentalmente, a mesma ética.

Em minha tese de doutorado (Albuquerque 2011) elaborei a noção de "o paradoxo da autenticidade". Ela se refere a dupla camada da pertença indígena no imaginário nacional. Como parte positiva desse imaginário, o indígena é tanto índice do passado nacional, a-histórico e apolítico, um lugar idílico, assim como na sua presença contemporânea nas cidades e na mobilização política por seus territórios tradicionais, desvencilhada desse campo idílico, o "moderno" torna-se um índice de ilegitimidade das demandas indígena. O paradoxo refere-se ao fato de que para continuarem como sociedade indígena esses coletivos assumem o conjunto de instrumentos do estado (educação, saúde, direitos e outros) que ao atualizar a presença indígena no contemporâneo tende a desvinculá-los do espaço idílico nacional onde o indígena tem sua 'reserva de mercado' na esfera da construção da nação. O dispositivo da autenticidade é um dos índices da presença contemporânea da assinatura colonial na esfera das ações museológicas e indígenas.

Como bem demonstrou Clifford (1999), os museus são uma zona de contato, o espaço institucional privilegiado de organização da representação do encontro colonial. O encontro colonial é eufeminizado e naturalizado nos museus, pois nesses espaços, "national sensibilities are respected, the exploits and connoisseurship of dominant groups are respected" (ibid.: 209). Portanto, tais espaços negam dar visibilidade ao caráter contemporâneo, plural e contra-hegemônico das tradiçóes indígenas. Na representação do encontro colonial que o museu veicula, o índio está fora da história da natureza (ele é ecologia) e da sociedade (ele precisa ser preservado, conservado para sobreviver), sua agência e contemporaneidade são minimizadas, quando não invisibilizadas. O museu ao mesmo tempo invisibiliza a heterogeneidade do espaço social nativo pois "such institution tend to reflect unifield community visions rather than overlapping, discrepant histories" (ibid.: 208), ele impõe um modelo homogêneo, normatizando e organizando arbitrariamente a historicidade e dinâmica da representação do outro.

Assim, as problemáticas dessas instituições objetificam os debates e discussões sobre a história, as formações nacionais e os projetos das coletividades nacionais. Não é por acaso que diversos países no mundo, e na América Latina com evidência, veem travando uma luta política pela memória dos períodos ditatoriais. Diversos museus dessa natureza foram inaugurados. Esses espaços são mais um elemento da institucionalização das políticas para a memória sobre as ditaduras militares ${ }^{6}$. Ao mesmo tempo, chama a atenção o fato de que no Brasil não exista nenhum museu dessa natureza, e o projeto de um "Memorial a Jango" vem sendo sabotado há anos no Distrito Federal? 
Desse modo, também não é de se espantar o fato de que no Brasil não exista nenhum museu da memória indígena sobre o contato. Neste tipo de espaço a auto-representação indígena objetificaria a distinção conceitual entre sociedade e cultura (Barth 1984, 1998, 2000). Devemos pensar no problema ético e conceitual de se representar "culturas", quando o interessante seria representar experiências coletivas ${ }^{8}$.

Um museu indígena ou "indigenizado" tende a ser um espaço onde um contexto etno-histórico é particularizado. E, fundamentalmente, onde se dá espaço ao investimento atual nas políticas culturais dos indígenas, em especial das novas gerações em suas performances. Um caso exemplar é o trabalho do grupo de rap Bro' Mc que, formado por jovens Guarani do Mato Grosso do Sul, utilizam o rap como espaço de autorepresentação, valorização cultural, autoestima e denúncia da violência e do preconceito ${ }^{\text {. }}$

$\mathrm{O}$ que esses jovens fazem é evidenciar o dispositivo da autenticidade. Mostrar suas ambiguidades e constrições. A performance desse grupo desmonta valores caros ao ocidente, torna evidente a assinatura colonial rasurando-a ao suspender a naturalidade do dispositivo da autenticidade. Essa suspenção coloca em discussão o valor das noções de continuidade e de origem. Sabemos como essas duas categorias são importantes na formação do pensamento ocidental, suas marcas são constitutivas do platonismo, da escolástica, do romantismo e do modernismo.

O Outro (os índios, os pobres, as crianças, as mulheres, e tantos outros coletivos) é um espaço privilegiado de redenção do ocidente em busca da origem, da pureza e da autenticidade. Seguindo Derrida em sua Gramatologia (2006), no centro dessa problemática está a natureza da mediação como condição da política, e com ela a eliminação da possibilidade da existência do "bom selvagem".

Assim, me parece existir também uma assinatura teológica (Agamben 2014) no dispositivo da autenticidade. No ocidente apenas pretensamente se expulsou a religião do campo da política. A religião, e suas marcas (assinatura teológica), ainda é uma das modalidades da gramática da política do ocidente. Pelo dispositivo da autenticidade os indígenas estão enrodilhados na assinatura colonial e teológica que reivindica a existência do espaço da origem ${ }^{10}$. Os exemplos contemporâneos são muitos, apresento abaixo apenas um.

\section{UMA FRACÃO DO INFINITO}

No momento em que escrevo esse artigo, o Centro Cultural do Banco do Brasil (CCBB) no Rio de Janeiro, um dos principais espaços de arte contemporânea do país, está promovendo (com o Ministério da Cultura), entre 13/01 a 04/04 de 2016, uma mostra retrospectiva do trabalho do multi-artista Guilherme Vaz. $O$ título da mostra é significativo, "Guilherme Vaz: Uma fração do infinito".

Uma parte mais recente da obra de Guilherme Vaz foi produzida a partir da década de 1980, quando o artista se dedica a uma série de atividades com os povos indígenas do oeste do Brasil. Em 1997 é nomeado presidente da Fundação Cultural de Ji-Paraná, em Rondônia, onde realiza, junto com indígenas GaviãoIkolen, o concerto Música em Manaos, apresentado no Teatro Amazonas em 1998. Em 2001 publicou o livro "Sinfonia das águas goianas" que, segundo o curador da mostra no CCBB, Franz Manata (2016), é "um livro 
antropológico com partituras musicais que investigam os hábitos dos sertões brasileiros". É nesse interim que o artista "resolveu acrescentar elementos sociológicos e antropológicos" (ibid.) aos seus trabalhos, e assim "grava mais de dez discos que sintetizam sua experiência nos últimos vinte anos passados no oeste do Brasil" (ibid.).

Portanto, uma parte da mostra do artista no CCBB está direcionada ao trabalho dele com povos indígenas e o "Sertão" brasileiro. Apresento abaixo alguns elementos significativos dessa parte da mostra, em seguida uma interpretação da mesma.

$\mathrm{Na}$ sala com essas obras o visitante se depara na entrada com as seguintes informações sobre a obra e o artista:

Guilherme Vaz acredita que existam dois tipos de artista, os que se relacionam com o 'Leste' e os que se relacionam com o 'Oeste' do mundo. Os do Leste se interessam pelo conforto das civilizações ocidentais e os do Oeste, pelo risco do desbravamento.

Nascido em Araguari, cidade do interior de Minas Gerais, ou como diria Guilherme, 'a 50 metros do fim do mundo', o artista se identifica com a vertente que se interessa pelo Oeste.

Depois de passar uma temporada entre Brasília, Salvador e Rio de Janeiro, entre meados dos anos 1960 e 1970, quando se envolve com música, cinema e artes plásticas, Guilherme ruma para o Oeste em busca de inspiração e intensidade.

A matriz de sua produção está no Sertão do Brasil. Durante vinte anos, dedica-se a investigar as raízes culturais do povo brasileiro, convivendo com sertanejos no Centro-Oeste e os indígenas do Norte do país. Essa vivência antropológica Ihe permitiu criar uma obra singular, inventiva e, sobretudo brasileira" (grifos meus).

\section{E um pequeno texto do próprio artista:}

Durante todo o período em que estive fora do circuito oficial da arte, eu estive trabalhando. Agora faço uma reparação geográfica, existe uma tendência de artistas que olham para o Leste de outros que olham para o Oeste. Pessoas que tendem para o Leste vão para Paris, Roma, etc., o leste do mundo, a civilização anterior. Pessoas que se interessam pelo desbravamento da América e para o mundo indígena tendem para o Oeste. Esses dois eixos são complementares, apesar de dialéticos e distintos (grifos meus).

A parte da mostra nesta sala é aberta com esta obra:

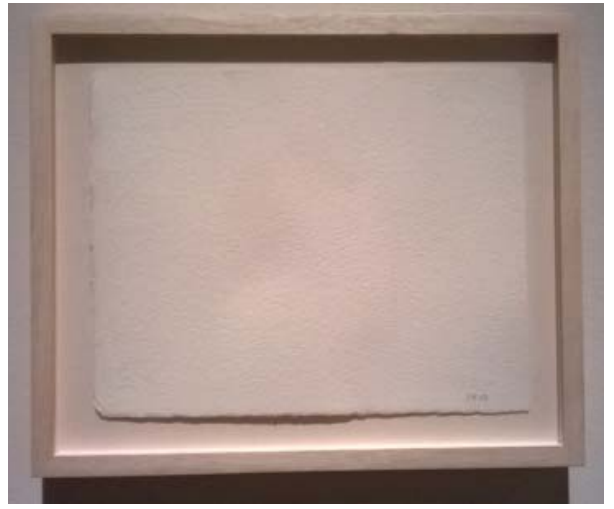


O título da obra é "Deus", escrito com letras de forma no canto inferior direito do quadro. Junto a essa obra está um texto manifesto intitulado "O deslitígio do universo", onde se lê:

A civilização não é um conceito único de homem. Portanto, estamos propondo o deslitígio do universo. Denominamos falso e artificial o litigio anterior, não servindo a diversidade. Queremos propor não somente a história do homem, mas também a dos falcões, a do gavião real do Amazonas, a dos cervos indianos, entre muitas outras. Estamos dizendo em todos os sentidos que todos os seres vivos têm linguagem e mesmo os minerais as possuem. Por que é importante esta posição para a arte praticada pelo homem atual e anterior? Em primeiro lugar e mais importante, ela combate o antropocentrismo letal presente na cultura e na arte ocidental. Existem sinais claros de arte em todos os seres vivos, inclusive nos translúcidos. Em segundo, e não menos importante, ela irmana o homem com todo o universo engrandecendo-o pela humilhação de sua arrogância. Estamos propondo a convivência de todas as civilizações do universo, conhecidas ou não.

Na sequência o visitante encontra um monitor de tv e fone de ouvido para assistir ao concerto Música em Manaos, citado mais acima. Junto está o texto:

A etnia Gavião-lkolen fechou comigo imediatamente. Fabricaram os violinos paleolíticos iritiraam. Ensaiaram as canções, escolhendo as melhores; ensaiaram e aperfeiçoaram os murmúrios de caça; colocaram suas roupas miseráveis em sacolas de plástico velhas e nos preparamos para o combate de enfrentar uma Orquestra Filarmônica bielorrussa dentro do Teatro Amazonas em Manaus, a cerca de mil e duzentos quilômetros do local onde estávamos (grifos meus).

Ao lado um conjunto com objetos indígenas:
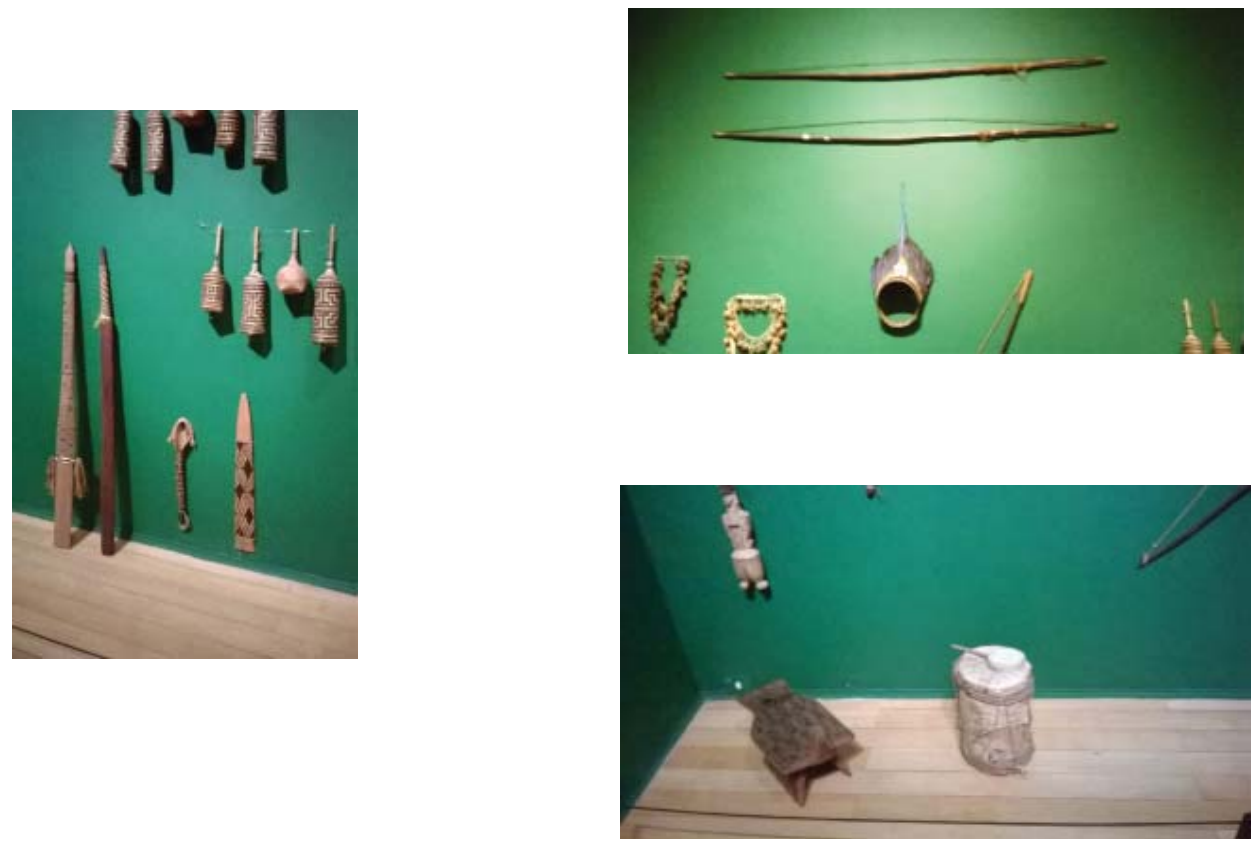
E o texto: "entre a década de 1980 e começo dos anos 2000, Guilherme Vaz percorreu o Brasil convivendo com diversas tribos indígenas. Os objetos apresentados nesta sala formam um conjunto afetivo, acumulado pelo artista no decorrer de suas vivências no Oeste do Brasil".

Em seguida haviam alguns quadros acompanhados do texto:

Apesar do meu trabalho passar longe do construtivismo, eu queria que a geometria indígena, feita à mão livre, atingisse uma determinada categoria. Nessa geometria existe uma filosofia, um pensamento do mundo. É uma geometria da vida. Uma das questões que me incomoda no construtivismo brasileiro é que tudo acontece distante da geometria indígena, distante dos sertões.

\section{Os quadros eram:}
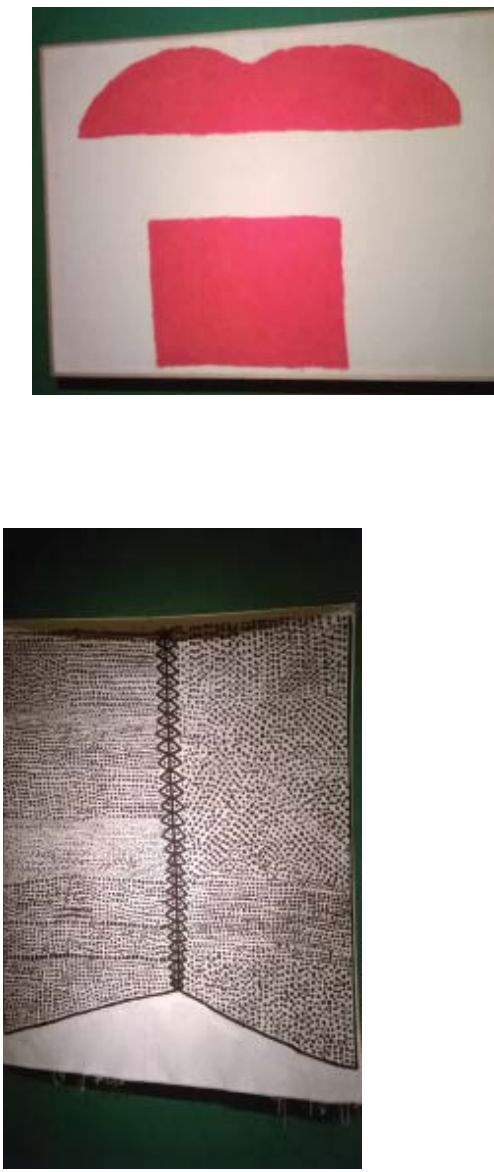
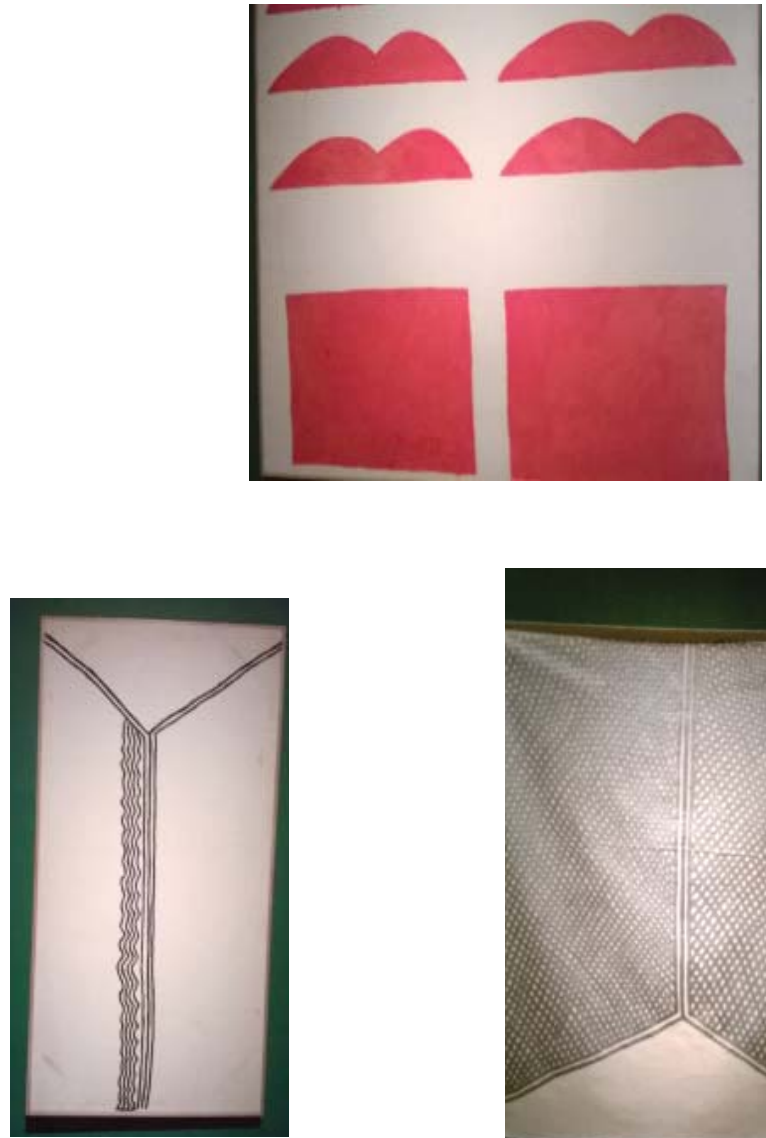

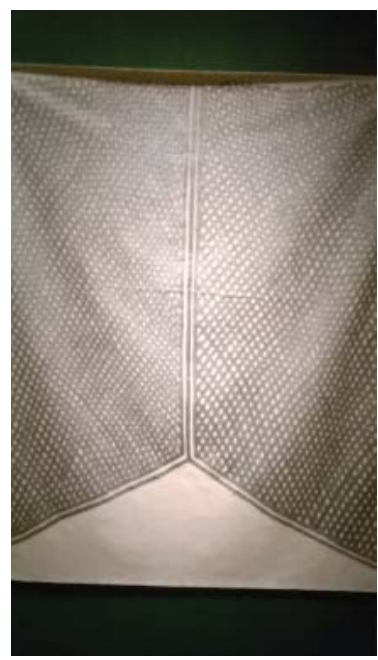


Como legenda dos quadros se lê, como artistas, "Guilherme Vaz e Carlos Bedurap Zoró" datado de 1999, e a descrição da obra, "Pinturas indígenas feitas por Carlos Bedurap Zoró da tribo Gavião-lkolen de Rondônia. Guilherme Vaz pedia ao indígena que reproduzisse suas pinturas corporais no tecido". Ao lado mais um pequeno texto: "você pode ordenar o mundo com uma geometria muito mais avançada, que assuma curvas. A curva é geométrica e você já viu coisa mais brasileira do que a curva? Além disso, ela não fecha e o Brasil é esférico e circular. A curva é social e includente".

Ao centro da sala haviam duas esculturas:
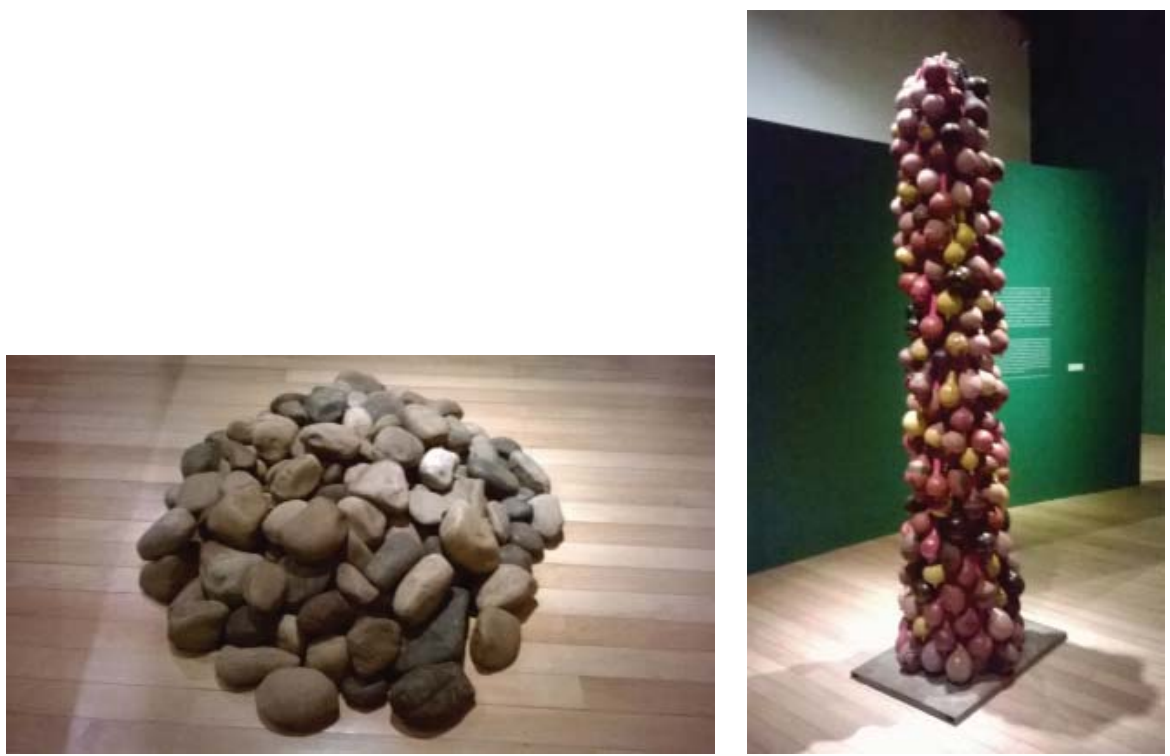

E um texto explicativo:

O maracá é o instrumento ícone da América, antiga e milenar, e dos povos indígenas da América, e me parece que mesmo da América do Norte, ele é, dessa forma, o som da américa atual e eterna, e o som do grande Oeste, aberto, e aponta para essa dimensão.

O nome da obra é "Totem" realizada no ano de 2015.

Esta parte da mostra e a sala fecham com uma obra intitulada "Desertos espirituais". A descrição da obra diz, "com essa partitura, Guilherme convida o público a construir suas próprias notações musicais em instrumentos inventados, ocidentais ou indígenas". A obra é esta: 


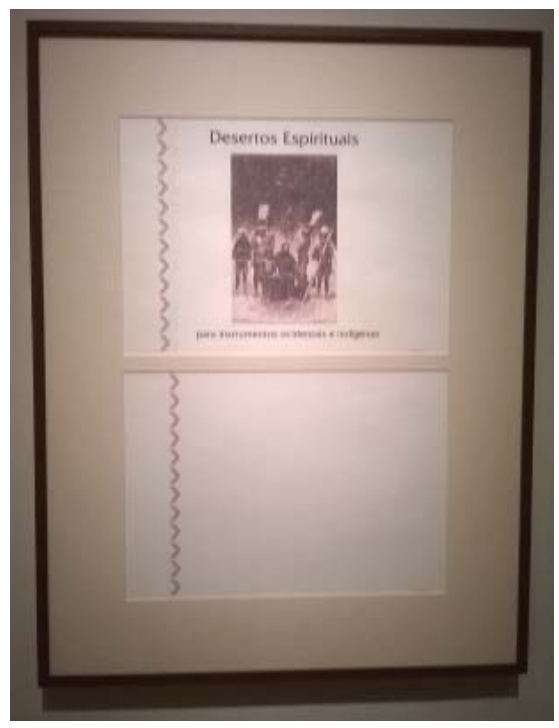

No quadro lê-se acima "Desertos espirituais", e abaixo, "para instrumentos ocidentais e indígenas".

Em resumo a exposição de Guilherme Vaz atualiza o dispositivo da autenticidade e dá visibilidade a assinatura colonial típica do modernismo europeu e brasileiro. Auto-'situando-se' em uma geografia imaginária em um dualismo fácil entre Leste e Oeste -, o artista reproduz os elementos do dualismo colonialista (orientalista), como por exemplo, as oposições entre "conforto das civilizações ocidentais" versus "o risco do desbravamento". Noções tipicamente colonialistas como a de desbravamento envolvem a retórica do artista na legitimação de seu "afastamento" da "civilização" para buscar uma "fração do infinito" como tropo de sua coragem para adentrar novos mundos, desconhecidos e exóticos.

A diferença (o outro) aparece como alegoria da ideia da aventura-viajem que é um traço tradicionalmente constitutivo da retórica modernista (Ribeiro 2008; 2009). Essa ideia é amplamente utilizada para legitimar esse "afastamento" do ocidente pelo artista. Nascido em uma cidade do interior de Minas Gerais, o artista considera que está 'a 50 metros do fim do mundo' o que Ihe permite a licença de caminhar ainda mais ao "Oeste".

Tendo sido uma "vivência antropológica" aquilo que lhe permitiu fazer uma arte "sobretudo brasileira", a exposição, construída a partir dessa geografia imaginária, promove o exotismo como parte dessa geografia e atualiza o dispositivo da autenticidade como um ato de tempo. Equaciona geografia e temporalidade como alegoria para o afastamento, a inspiração, o desbravamento, as raízes e a intensidade. Todos os elementos também constituintes da gramática do modernismo brasileiro em relação ao patrimônio nacional. $E$, desse modo, a metáfora do próprio país, do povo e, fundamentalmente, da Estado-nação. O sertão é aqui a grande metáfora do país, alegoria que serve ao artista como capital simbólico diferencial no campo das artes plásticas. Portanto, ao mesmo tempo que 
atualiza os museus coloniais e os objetos-fetiches, atualiza o valor da noção de patrimônio nacional assim como a metáfora da nação na objetificação metonímia dos povos indígenas.

No centro dessas metáforas, e dessa geografia imaginária, não é surpresa encontrar a noção de deus e de espiritualidade usadas como mediador universal da experiência humana, a assinatura teológica. O “Deus" (em) Branco e mudo aparece duas vezes, uma na entrada e outra na saída, como espaço a ser preenchido. Um religare no qual a arte pretende aparecer como denominador comum da experiência indígena-Oeste e ocidental-Leste.

Junto à presença desse deus mudo há um manifesto. Sintomaticamente um manifesto intitulado "deslitígio do universo". Um religare. Nele há expresso um neologismo que aparenta ser uma defesa do fim das contestações, já que o litígio, em termos jurídicos, rege exatamente a ação ou controvérsia judicial, e, como figura de linguagem, significa o conflito de interesses, a contenda ou a pendência. Como centro do fim das contestações e abertura para o "Universo", a arte seria a grande mediadora, não somente entre os homens e as "civilizações" (inclusive as "não conhecidas"), mas também junto aos animais.

Em sua descrição do concerto Música em Manaos, o artista arrola uma série de categorias "orientalistas": paleolíticos como primitivos; murmúrios como falta da condição da linguagem completa; roupas miseráveis em sacolas de plástico velhas como condição da sua pobreza; combate de enfrentar uma Orquestra Filarmônica como metáfora militar para a sua condição de diferença e inferioridade, o encontro colonialista como ato de guerra, e, a cerca de mil e duzentos quilômetros do local onde estávamos como componente dessa geografia imaginada do exotismo como ato de tempo.

$\mathrm{Na}$ sequência um conjunto metonímico típico da assinatura colonial, objetos-fetiches que objetificam, aqui, segundo o artista, um "conjunto afetivo" seu, próprio. Completamente desprovidos de contextualização, os objetos-museus são o fetiche que permite ao artista se instalar no meio deles, falar de si através do outro, se fazer presente através desse outro que visível está ausente. O ser presente é o artista, sua ação, sua agência que toma valor positivo e cria capital simbólico às custas de invisibilizar as pessoas e a condição concreta da agência dos objetos em seus contextos nativos.

Da mesma forma está condicionada a uma sugestão bastante ampla - que a torna um ato sem pensamento -, quando o artista se refere a uma "geometria indígena" que remeteria a uma pretensa "filosofia, um pensamento do mundo" que o visitante apenas pode imaginar como seria. Possivelmente atualizando o repertório colonialista de sempre e já expresso em distintos formatos no interior da sala de exposição.

As pinturas são o ponto alto da produção de capital simbólico do artista e seu diferencial no campo das artes. Ao remeter o visitante ao fato de que os quadros foram feitos a quatro mãos, a arte do indígena se transforma no que Price (2000) chamou de pedigree, que se torna arte apenas porque esta legitimada e auferida pela assinatura do artista 'de verdade', aquela ao qual está dada a permissão de produzir os sentidos da arte.

Nesse mesmo conjunto, de forma inusitada, atualiza-se outro motor do tropos nacional: a curva com seu sentido sempre dúbio. Diz o artista, "você já viu coisa mais brasileira do que a curva?". Equacionar Brasil com curva não é nada novo. A novidade espantosa é pensá-la como um denominador comum para a condição de nossa enorme clivagem social ao afirmar que "a curva é social e includente". 
A pretensão de conferir sentido, ao mesmo tempo em que promove generalizações impressionantes, fica patente com a obra "Totem" feita com maracás. Ao situá-los como índice comum da América inteira, o artista generaliza e retira qualquer condição de emergência de sentidos próprios aos usos diferenciados, políticos e contextuais dos objetos rituais.

O visitante encerra o trajeto da sala com a obra "Desertos espirituais". Nela há um convite para que o visitante construa "suas próprias notações musicais em instrumentos inventados, ocidentais ou indígenas". Como a natureza da obra não permite intervenção e nem o espaço da sala se propõe a isso, resta ao visitante imaginar instrumentos, sons?, em um grande deserto "espiritual". A curva que pretende incluir é por uma metafísica. "Deus" (assinatura teológica) no jogo de uma geografia imaginada (assinatura colonia/) em busca da origem, do novo e do autêntico. Vazio, distante, exótico, Oeste, alegorias da arte que "desbrava" uma fração do "infinito"... de Guilherme Vaz.

No centro dessa sala de exposição havia uma obra de 1970 que se constituiu de um caminho estreito formado por duas paredes paralelas. Nesse caminho o visitante é instigado a percorrer o pequeno trecho vazio onde está escrito nas paredes, na entrada e na saída, o texto, "Ande para qualquer lugar, durante qualquer tempo, por qualquer distância, de qualquer maneira". A frase deveria ter sido levada ao pé da letra. Na sua força retórica, imagem e poder de deslocamento, cabe muito bem nela a possibilidade de desativar o dispositivo da autenticidade. De romper com essa geografia imaginada e conferir ao contemporâneo sua promessa, dar ao presente os encontros, não os pretendidos, mas os possíveis. Em uma pragmática ali ausente, deveria ter-se constituído junto com ela a presença e a agência indígena contemporânea.

No artigo "O que é o contemporâneo?", Agamben (2014:33) termina o texto lembrando Walter Benjamin "quando escrevia que o índice histórico contido nas imagens do passado mostra que estas chegarão a legibilidade somente num determinado momento da sua história". E que devemos todos ser contemporâneos "não exclusivamente do nosso século e do 'agora', mas também das suas figuras nos textos e nos documentos do passado" (ibid.).

Portanto, é a tarefa política de hoje debater os efeitos da assinatura colonial e a ação do dispositivo da autenticidade. Assim como procurar promover o movimento de sua contradição e embaralhar as categorias que pretendem administrar a diferença circunscrevendo-a em espaços de gestão e domesticação de sua condição política contra hegemônica ${ }^{11}$.

\section{CONCLUSÃO}

Segundo Gonçalves (2002:14), a noção de "objetificação cultural", serve para "pensarmos os processos de invenção de 'culturas' e 'tradições' em modernos contextos nacionais". O termo objetificação cultural é uma noção que Handler utiliza a partir do trabalho de Benjamin Whorf (1978), para quem "a objetificação refere-se à tendência da lógica ocidental a imaginar fenômenos não materiais (como o tempo) como se fossem algo concreto, objetos físicos existentes" (apud Gonçalves 2002:14). Handler (1984: 55-6) escreveu "faço uso da noção de 'objetificação cultural' para me referir à materialização imaginativa de realidades humanas em termos de discurso teórico baseado no conceito de cultura". 
Como argumenta Gonçalves (2002:15), para Handler a "objetificação cultural" "é determinada por uma 'lógica' embutida nas línguas e culturas ocidentais", mas, "uma vez que essa 'lógica' não existe independentemente dos seus usos, o platonismo de Handler não nos ajuda muito a lidar com a complexidade e a especificidade dos diversos processos de objetificação cultural". Desse modo, Gonçalves (ibid.) acredita que o pesquisador deve perguntar: "quem objetifica? O que é objetificado? Como isso é feito? Com quais propósitos?". Desse modo, ainda segundo o autor:

Seria mais produtivo se incluíssemos em nosso campo de análises os usos que são feitos dessas "entidades sócio-científicas" por grupos e categorias em diferentes situações socioculturais. O que nos possibilitaria pensá-la também como estratégias, como ações contingentes e dotadas de propósitos, em vez de tão somente atualizações de uma "lógica cultural ocidental" (ibid.).

Foi isso o que pretendi fazer aqui ao realizar um ensaio sobre o dispositivo da autenticidade e a assinatura colonial que é um dos traços dos objeto-museu / objeto-fetiche.

Os indígenas também se utilizaram dessa suposta "lógica ocidental" ao inventarem tradições em arenas interculturais e nos museus indígenas. Assim, eles também parecem ter "lançado mão" da "objetificação cultural" da sua própria cultura material a fim de adquirir "capital simbólico" nessas arenas, onde o modelo hegemônico da tradição indígena é exatamente o do museu.

Desse modo, sigo a orientação de Rognon (1991) quando aponta para a problemática do que é traduzir como procedimento analítico. Para ele "essa questão deve ser levantada para evitar que se interprete sem reduzir a cultura a um sistema de signos" (ibid.: 139). Ao interpretar o outro, devemos "no mesmo movimento interpretar nossas próprias categorias, que manejamos para manter um discurso sobre o outro. (...) E mostrar o que há neles de impensado, suas conotações implícitas e inconscientes" (ibid.: 139-40). É neste sentido de interpretação que "os objetos arcaicos devem ser interpretados e não mais apenas descritos ou 'lidos'. (...) compreender simultaneamente o outro e o mesmo (...) o sincretismo e o tradicionalismo" (ibid.: 141-2). Traduzir, em suma, "compreender o mecanismo de um fenômeno que diz respeito atualmente a todas as culturas: a interpretação e a apropriação das crenças e dos valores de outrem" (ibid.: 142). Isso é necessário para não naturalizar as normatizações. Assim, devemos finalmente questionar com força:

O que é o tradicionalismo, o culto da tradição? De onde emerge, quem são os seus apregoadores, como é imposto aos que vivem ainda na tradição? Que processos ideológicos são empregados para que o novo Estado, recentemente incluído no concerto das nações, deixe de aparecer como um monstro frio e torne-se o fiador da tradição, do costume, da riqueza cultural de um conjunto de comunidades aldeãs? Como a imagem de si imposta pelo missionário é interiorizada? E como a imagem de sua cultura construída pelo antropólogo é reapropriada? (Rognon 1991:143).

Comecei esse artigo com a menção ao ensaio de Agamben (2014) sobre a nudez. Nele Agamben (idem) argumenta que em nossa relação contemporânea com a nudez há impressa uma assinatura teológica e que é essa assinatura que nos permite a experiência do fetiche sexual. Em outro artigo Agamben (2007) tematiza o que chama de dispositivo da pornografia, nele o autor argumenta que o que o dispositivo da pornografia procura neutralizar é 
o seu potencial profanatório, "o que nele acaba sendo capturado é a capacidade humana de fazer andar em círculo os comportamentos eróticos, de os profanar, separando-os do seu fim imediato" (ibid.:78) e que:

Todo dispositivo de poder sempre é duplo: por um lado, isso resulta de um comportamento individual de subjetivação e, por outro, da sua captura numa esfera separada. Em si mesmo, o comportamento individual não traz, muitas vezes, nada de reprovável e até pode expressar uma intenção liberatória; reprovável é eventualmente — quando não foi obrigado pelas circunstâncias ou pela força - apenas o fato de se ter deixado capturar no dispositivo. Não é o gesto impudente da pornostar nem o rosto impassível da manequim, como tais, que devem ser questionados; infames são, isso sim —-política e moralmente - o dispositivo da pornografia, o dispositivo do desfile de moda, que os desviaram do seu uso possível.

O Improfanável da pornografia - qualquer improfanável - baseia-se no aprisionamento e na distração de uma intenção autenticamente profanatória. Por isso é importante toda vez arrancar dos dispositivos — de todo dispositivo - a possibilidade de uso que os mesmos capturaram. A profanação do improfanável é a tarefa política da geração que vem (ibid.: 79).

Se de fato está correto Agamben (apud Castro 2012:164), estamos vivendo "a fase extrema do desenvolvimento capitalista", em uma "gigantesca acumulação e proliferação de dispositivos", então continua sendo pertinente nomear e definir estes dispositivos. Acredito que o dispositivo da autenticidade é um deles. Portanto, como "não se trata nem de suprimir os dispositivos nem de imaginar-se ingenuamente um bom uso" (ibid.), devemos profanálo, rasurando a assinatura colonial e arrancando do dispositivo da autenticidade as variadas outras possibilidades dos usos da diferença.

Marcos Alexandre dos Santos Albuquerque é Doutor em Antropologia Social pela Universidade Federal de Santa Catarina e Professor Adjunto da Universidade do Estado do Rio de Janeiro (UERJ) no Programa de Pós-graduação em Ciências Sociais (PPCIS). 


\section{NOTAS}

1 Uma primeira versão desse artigo foi apresentada no I Seminário do Laboratório de Estudos Sobre Tradições (LETRA) “Lições da Tradição: território, cultura e identidade", na UFCG, em Campina Grande, entre 3 a 5 de Junho de 2014, agradeço a Rodrigo Grunewald e aos organizadores o convite. Uma segunda versão foi apresentada no I Seminário de Etnologia e Museus, durante a VII Semana de Antropologia: Desafios da Alteridade, promovido pelo PPGA e Museu de Arqueologia e Etnologia da UFPR, em Curitiba, entre 24 a 27 de agosto de 2015. Agradeço a Laura Pérez Gil e aos organizadores o convite. E uma terceira na XI RAM, no GT “Museos, Objetos e Imágenes de Otros y de Sí: Arte, Política y Antropología", entre 30/11 e 04/12 de 2015 em Montevideo, Uruguai. Agradeço às coordenadoras Barbara Arisi, Marian Moya e Helena Schiel o aceite do paper. Agradeço imensamente aos colegas e alunos presentes nesses eventos a oportunidade do debate e as sugestões apresentadas.

2 http://en.wikipedia.org/wiki/Exoticism.

3 Nesse sentido é sintomática a história e o destino de Saartjie Baartman. Levada da África para à França para "atuar" como atração exótica em zoológicos humanos e círculos aristocráticos, morreria em Paris em 1815, aos 27 anos de idade, de uma combinação de pneumonia e doenças venéreas. O seu corpo foi vendido ao Musée de l'Homme. O esqueleto e um molde do seu corpo (além de seus órgãos genitais e seu cérebro), ficaram expostos no museu até 1974. Nelson Mandela, em 1994 (ao se tornar presidente da África do Sul), exigiu formalmente à França a devolução dos restos de Saartjie. O pedido só seria atendido em 6 de março de 2002.

4 Nesse sentido é sintomática a história e o destino de Saartjie Baartman. Levada da África para à França para "atuar" como atração exótica em zoológicos humanos e círculos aristocráticos, morreria em Paris em 1815, aos 27 anos de idade, de uma combinação de pneumonia e doenças venéreas. O seu corpo foi vendido ao Musée de l'Homme. O esqueleto e um molde do seu corpo (além de seus órgãos genitais e seu cérebro), ficaram expostos no museu até 1974. Nelson Mandela, em 1994 (ao se tornar presidente da África do Sul), exigiu formalmente à França a devolução dos restos de Saartjie. O pedido só seria atendido em 6 de março de 2002.

5 Para maiores detalhes sobre o caso brasileiro ver Albuquerque 2011, 2015a e 2015b.

6 Os casos mais significativos são o Espacio Memoria y Derechos Humanos (2004) na Argentina, e o Museo de la Memoria y los Derechos Humanos (2010) no Chile.

7 Ver a reportagem "Governador de Brasília cassa Jango pela segunda vez" do site ConversaAfiada em: http://www.conversaafiada.com. br/brasil/governador-de-brasilia-cassa-jango-pela-segunda-vez. E a campanha pelo Memorial Liberdade e Democracia João Goulart em: http://www.kickante.com.br/campanhas/memorial-liberdade-e-democracia-joao-goulart.

8 Por exemplo, imagino o impacto formativo para a população se tivéssemos um museu que narrasse conceitualmente a experiência dos indígenas Xokleng (SC) com o processo de "pacificação".

9 Ver, p.ex. o clip musical "Eju Orendive" em: https://www.youtube.com/watch?v=oLbhGYfDmQg.

10 Na primeira metade do séc. XX, o uso generalizado da categoria Missão por pesquisadores, artistas, administradores e missionários, indica um desses nós semânticos que une, no dispositivo da autenticidade, as assinaturas colonial e teológica. A categoria Missão (muitas vezes usada em maiúscula) funde secular e sagrado, tempo e espaço. Sobre as categorias de tempo e espaço na relação entre antropologia, colonialismo e teologia, ver Fabian (2013), principalmente no capitulo 01 o tópico "Do tempo sagrado ao secular: o viajante filosófico".

11 Tais enquetes, dentre outros instrumentos de pesquisa, subsidiaram os estudos de Barbary e Urrea (2004) que contabilizaram a população afrocolombiana em cerca de $20 \%$ da população nacional.

12 Foi exatamente isso o que fez Adriano Pedrosa e Lilia Schwarcz com a exposição "Histórias Mestiças" realizada no Instituto Tomie Ohtake, São Paulo-SP, em 2014. Assim como o livro "Pérola imperfeita: A história e as histórias na obra de Adriana Varejão" feito em parceria pela artista plástica Adriana Varejão e a antropóloga Lilia Schwarcz. Nesse mesmo sentido os filmes etnográficos "Cannibal Tours" (1988) de Dennis O'Rourke e "In and out Africa" (1993) de llisa Barbash \& Lucien Taylor são um bom exemplo. Ver também os artigos de Kasfir (2008), Appiah (2010) e Goldstein (2012). 


\section{REFERÊNCIAS BIBLIOGRÁFICAS}

AGAMBEN, Giorgio. 2006. Che cosa è un dispositivo? Roma: Nottetempo. 2007. "Elogio da Profanação". In Profanações. São Paulo: Ed. Boitempo.

2014. Nudez. Belo Horizonte: Editora Autêntica.

ALBUQUERQUE, Marcos. 2011. O Regime Imagético Pankararu (Tradução Intercultural na Cidade de São Paulo). Tese de Doutorado. Florianópolis: PPGAS - UFSC.

2015a. “O praiá Pankararu: objeto-fetiche modernista". PROA - Revista de Antropologia e Arte 5.

2015b. “O Exotismo Inverso Pankararu: Performance e imagem indígena em contexto urbano”. In C. Peixoto e B. Copque. (Orgs.) Etnografias visuais: análises contemporâneas. Rio de Janeiro: Garamond.

APPIAH, Kwame Anthony. 2010. “Será o Pós em Pós-Modernismo o Pós em Pós-Colonial?" Disponível em: http://artafrica.letras.ulisboa.pt/uploads/docs/2016/04/18/5714df1ec40c3.pdf.

BARTH, Fredrik. 1984. "Problems of Conceptualizing Cultural Pluralism, with Illustrations from Somar, Oman". In D. Maybury-Lewis (ed.). The Prospects for Plural Society. Washington: The American Ethnological Society.

.1998. "Grupos Étnicos e suas Fronteiras". In P. Poutigrat e J. Streiff-Fenart. Teorias da Etnicidade. São Paulo: Editora da UNESP.

2000. O Guru, o Iniciador e Outras Variações Antropológicas. Rio de Janeiro: Contra Capa.

BOAS, Franz. 2004. "Os princípios da classificação etnológica". In G. W. Stocking Jr. (org). Franz Boas - A formação da Antropologia americana - 1883-1911. Antologia. Rio de Janeiro: Contraponto/UFRJ.

CASTRO, E. 2009. Vocabulário de Foucault. Belo Horizonte: Autêntica Editora.

2012. Introdução a Giorgio Agamben: Uma Arqueologia da Potência. Belo Horizonte: Autêntica Editora.

CAZARRÉ, Marcelo Macedo. 2003. “Exotismo e Folclorismo na obra de Arthur Napoleão (1843-1925)”. UFRGS. Disponível em: http://conservatorio.ufpel.edu.br/admin/artigos/arquivos/Exotismo\%20e\%20Folclorismo\%20na\%20obra\%20de\%20 Arthur\%20Napoleao.pdf. Acessado em: 19/01/2011.

CLIFFORD, James. 2002. "Sobre o Surrealismo Etnográfico". In A experiência etnográfica: Antropologia e Literatura no séc. $X X$. Rio de Janeiro: Ed. UFRJ.

1999. "Museums as Contact Zones". In Routes: Trave/ and Translation in the Late Twentieth Century. Cambridge: Harvard University Press.

DERRIDA, Jacques. 2006. Gramatologia. São Paulo: Perspectiva.

FABIAN, Johannes. 2013. O tempo e o outro: Como a antropologia estabelece seu objeto. São Paulo: Ed. Vozes.

FOUCAULT, Michel. 1977. História da Sexualidade I: a vontade de saber. Rio de Janeiro: Graal.

1987. Vigiar e Punir: nascimento da prisão. Petrópolis: Vozes.

1996. "A Ordem do Discurso". Aula inaugural no College de France. Pronunciada em 2 de dezembro de 1970.

São Paulo. Ed. Loyola. 
FOUCAULT, M. GOLDSTEIN, Ilana. 2012. “Autoria, autenticidade e apropriação: reflexões a partir da pintura aborígine australiana". Revista brasileira de Ciências Sociais 27(79)

GONÇALVES, J. R. S. 2002. A Retórica da Perda: os discursos do patrimônio cultural no Brasil. Rio de Janeiro: Editora UFRJ/Iphan.

HANDLER, R. 1984. “On Sociocultural Discontinuity: Nationalism and Cultural Objectification in Quebec". Current Anthropology 25(1)

JONES, Alden. 2007. “This Is Not a Cruise”. Disponível em: http://www.thesmartset.com/print/article/article08060708. aspx. Acessado em: 19/01/2011.

KASFIR. Sidney. 2008. “Arte africana e autenticidade: um texto com uma sombra”. Disponível em: http://artafrica.letras.ulisboa.pt/uploads/docs/2016/04/18/5714e3e244f01.pdf.

MANATA, F. 2016. “Guilherme Vaz: Uma fração do infinito”. In Guilherme Vaz: Uma fração do infinito. Folder da exposição. Centro Cultural do Banco do Brasil (CCBB). Rio de Janeiro, Ministério da Cultura. Disponível em: http://culturabancodobrasil. com.br/portal/wp-content/uploads/2015/12/Guilherme-Vaz-Baixe-o-folder-aqui.pdf. Acessado em: 18/02/2016.

MOTTA, Antonio. 2006. “A África Fantasma de Michel Leiris”. In M. Grossi, J. Cavignac e A. Motta. Antropologia Francesa no séc. XX. Recife: Fundação Joaquim Nabuco / Editora Massangana.

PEIXOTO, Fernanda Areas. 2006. "O nativo e o Narrativo: os trópicos de Lévi-Strauss e a África de Michael Leiris". In M. Grossi, J. Cavignac e A. Motta. Antropologia Francesa no séc. XX. Recife: Fundação Joaquim Nabuco / Editora Massangana.

PRICE, Sally. 2000. Arte Primitiva em Centros Civilizados. Rio de Janeiro: Editora UFRJ.

PUGA, Rogério. No prelo. “Exotismo”. In C. Ceia (dir.). Dicionário de Termos Literários. Lisboa: Editorial Verbo.

RIBEIRO, Marcelo Rodrigues Souza. 2008. Da economia política do nome de 'África': a filmografia de Tarzan. Dissertação de Mestrado. Florianópolis: PPGAS-UFSC.

2009. "O caminho, a experiência e a aventura". Revista de Ciências Humanas (UFSC) 43

ROGNON, F. 1991. Os Primitivos, nossos contemporâneos. Campinas, SP: Papirus.

SPIVAK, G. 2010 [1985]. Pode o Subalterno Falar? Belo Horizonte: Editora UFMG. 


\section{RESUMO}

Os museus, os museus indígenas e "indigenizados" vem se apresentando como um importante espaço de reflexão antropológica. Neste artigo apresento alguns tópicos do debate sobre as modalidades pelas quais a assinatura colonial se relaciona com a gestão metonímica do passado e do contemporâneo nessas instituições. Para isso, exponho alguns elementos teóricos e problematizações sobre os efeitos do dispositivo da autenticidade na promoção intercultural de tradições indígenas.

PALAVRAS-CHAVE: indígenas; museus; colonialismo; autenticidade; modernismo

\section{Colonial signature and authencity apparatus in Museums}

\section{ABSTRACT}

Museums and indigenous museums have been presented as an important scenario to anthropological reflexion. In this article I present some topics of debate about the modalities in which the colonial signature relates itself to the metonymic management of the past and the contemporary in these institutions. For this, I present some theoretical elements and issues about the effects of the authenticity apparatus in the intercultural promotion of indigenous traditions.

KEYWORDS: indigenous; museums; colonialism; authenticity; modernism 